\title{
Effect of High Glucose on Basal Intracellular Calcium Regulation in Rat Mesangial Cell
}

\author{
Joon Ho Song a Sang Yong Jung ${ }^{b}$ Seong Bin Hong ${ }^{c}$ Moon-Jae Kim ${ }^{a}$ \\ Chang Kook Suh ${ }^{b}$
}

Departments of a Nephrology and Hypertension, bPhysiology and Biophysics, and cEndocrinology and Metabolism, Inha University College of Medicine, Inchon City, South Korea

\author{
Key Words \\ Calcium · Diabetes $\cdot$ Rat model
}

\begin{abstract}
Background: A number of cellular mechanisms are critically dependent on intracellular $\mathrm{Ca}^{2+}$ homeostasis. A sustained increase in the intracellular $\mathrm{Ca}^{2+}$ concentration $\left(\left[\mathrm{Ca}^{2+}\right]_{\mathrm{i}}\right)$ is capable of activating a number of potentially harmful processes including phenotype change to secretory type, dysregulated cell proliferation, and cell injury and death. Mesangial cells (MCs) play an important role in the pathophysiology of diabetic nephropathy. Methods: We evaluated the effect of high glucose on basal $\left[\mathrm{Ca}^{2+}\right]_{\mathrm{i}}$ in the unstimulated state and identified its contributing pathways. MCs were isolated and cultured from Sprague-Dawley rats. $\left[\mathrm{Ca}^{2+}\right]_{\mathrm{i}}$ was measured by fluorometric technique with fura-2AM. Results: In a dosedependent manner, superfusion of MCs with Tyrode's solution containing high glucose (30 and $50 \mathrm{mM}$ ) induced a delayed spontaneous increase in $\left[\mathrm{Ca}^{2+}\right]_{i}$, which was not found in those with normal $(5.5 \mathrm{mM})$ glucose or mannitol. The high glucose-induced increase in $\left[\mathrm{Ca}^{2+}\right]_{i}$ occurred through transmembrane influx of extracellular $\mathrm{Ca}^{2+}$ and was blocked by SKF96365, an inhibitor of storeoperated $\mathrm{Ca}^{2+}$ influx. $\mathrm{Na}^{+}-\mathrm{Ca}^{2+}$ exchanger (NCX) activity, a major channel regulating basal $\left[\mathrm{Ca}^{2+}\right]_{i}$, and the clearing
\end{abstract}

ability of intracellular $\mathrm{Ca}^{2+}$ were depressed after MCs were cultured in high-glucose medium. Western blot analysis revealed the decreased expression of a $70-\mathrm{kD}$ NCX protein in MCs cultured in high-glucose medium. Conclusions: A high-glucose concentration induced a spontaneous increase in basal $\left[\mathrm{Ca}^{2+}\right]_{i}$ of $\mathrm{MCs}$ without stimulation. There was a decrease in the activity of NCX in the high-glucose condition, which seems to occur at the level of protein expression. The present results provide a novel insight into the mechanisms of diabetic nephropathy in that intracellular $\mathrm{Ca}^{2+}$ homeostasis is an important secondary messenger and a mediator in hormonal signaling.

Copyright $@ 2003$ S. Karger AG, Basel

\section{Introduction}

The early pathophysiological changes in diabetic kidney diseases are characterized by hyperfiltration and microalbuminuria, and later on by the development of complex metabolic and structural changes [1, 2]. Mesangial cells (MCs) are known to be involved in these pathologic sequences through the mediation of altered glomerular hemodynamics, cell proliferation, and matrix production [1-3].

\section{KARGER \\ Fax +41613061234 \\ E-Mail karger@karger.ch \\ www. karger.com \\ (c) 2003 S. Karger AG, Basel \\ 0250-8095/03/0235-0343\$19.50/0 \\ Accessible online at: \\ www. karger.com/ajn}

Chang Kook Suh, PhD

Department of Physiology and Biophysics, Inha University College of Medicine

7-206, Sinhung-Dong, Jung-Gu

Inchon City, 400-103 (South Korea)

Tel. +82 328900921 , Fax +82 32884 5997, E-Mail cksuh@inha.ac.kr 
Cytosolic calcium $\left(\mathrm{Ca}^{2+}\right)$ activity, or intracellular $\mathrm{Ca}^{2+}$ concentration $\left(\left[\mathrm{Ca}^{2+}\right]_{i}\right)$, is an important biological signal in the control of protein secretion, contraction, development and apoptosis in a wide variety of cells. Many cellular functions critically depend on $\left[\mathrm{Ca}^{2+}\right]_{\mathrm{i}}[4-6]$ and a sustained elevation in $\left[\mathrm{Ca}^{2+}\right]_{i}$ is capable of activating a number of potentially harmful cellular processes including phenotypic change, dysregulated cell proliferation, cell injury, apoptosis, and death [6-8].

Several studies have been done on $\mathrm{Ca}^{2+}$ regulation in MCs. Most of these studies focused on the $\left[\mathrm{Ca}^{2+}\right]_{\mathrm{i}}$ responses of MCs to vasoactive hormones, such as angiotensin II, arginine vasopressin, thromboxane analogues, which are related to the contractile properties of MCs. Loss of the contractile responsiveness to vasoactive hormones in MCs is related to hyperfiltration and microalbuminuria in the early course of diabetic nephropathy [9, 10]. Recent investigations revealed that the alteration in vasoconstrictor-induced $\mathrm{Ca}^{2+}$ signaling by high glucose contributes to this phenomenon [11-13].

However, these findings are related solely to the early part of the pathophysiological process in diabetic nephropathy. As the disease progresses, a variety of cellular dysfunctions in the MCs incorporate into the whole complex feature of diabetic nephropathy, such as the phenotypic change to the secretory and proinflammatory cells, an abnormal cell cycle, or cell injury and death. Since the change in $\left[\mathrm{Ca}^{2+}\right]_{\mathrm{i}}$ is comprehensively related to these pathophysiological processes [6], we have focused on the basal intracellular $\mathrm{Ca}^{2+}$ homeostasis of the MCs in a condition without any stimulation by vasoactive hormones, which has rarely been investigated in MCs. The aims of the present study are to evaluate the effect of high glucose on basal $\left[\mathrm{Ca}^{2+}\right]_{\mathrm{i}}$ of MCs, and to identify the contributing $\mathrm{Ca}^{2+}$ pathways, and to focus on $\mathrm{Na}^{+}-\mathrm{Ca}^{2+}$ exchanger (NCX) function.

\section{Materials and Methods}

\section{Isolation and Cell Culture of Rat Mesangial Cells}

The kidneys of Sprague-Dawley rats (80-100 g/body weight) were removed and homogenized under sterile conditions. The glomeruli were isolated from the homogenate by sequential sieving and collected on a $75-\mu \mathrm{m}$ sieve. After incubation with $0.25 \%$ trypsin and $0.02 \%$ EDTA in PBS (pH 7.4) for 30 min, the glomeruli were plated in tissue culture dishes containing Dulbecco's modified Eagle's medium/F-12 nutrient mixture (DMEM/F-12) supplemented with $5.5 \mathrm{~m} M$ glucose, $20 \%$ heat-inactivated fetal bovine serum, $100 \mathrm{U} / \mathrm{ml}$ penicillin, and $100 \mu \mathrm{g} / \mathrm{ml}$ streptomycin. To characterize cell outgrowths, immunohistochemical staining was performed for vimentin, desmin, and cytokeratin. To evaluate the basal $\left[\mathrm{Ca}^{2+}\right]_{i}$ change and transmembrane $\mathrm{Ca}^{2+}$ flux, superfusion with various experimental solutions was performed on the cells at subconfluence or at confluence with $0.05 \%$ trypsin $/ 0.02 \%$ EDTA. Cells between 5 and 10 passages were used. To obtain quiescent cells, MCs were maintained in DMEM/F-12 media supplemented with $0.5 \%$ fetal bovine serum for $24 \mathrm{~h}$. To evaluate the change in function and protein expression of NCX, subconfluent quiescent MCs were further incubated in DMEM/F-12 media containing 5.5 or $30 \mathrm{~m} M$ glucose or $30 \mathrm{mM}$ mannitol for 3 days.

\section{Experimental Solutions}

The changes in basal $\left[\mathrm{Ca}^{2+}\right]_{\mathrm{i}}$ and transmembrane $\mathrm{Ca}^{2+}$ flux were examined by superfusion of the solutions containing variable glucose concentrations. Tyrode's solution was used as basal solution. The composition of Tyrode's solution in the present study was as follows: $5 \mathrm{~m} M$ HEPES, $140 \mathrm{~m} M \mathrm{NaCl}, 4 \mathrm{~m} M \mathrm{KCl}, 2 \mathrm{~m} M \mathrm{CaCl}_{2}, 1 \mathrm{~m} M$ $\mathrm{MgCl}_{2}, 1 \mathrm{~m} M \mathrm{NaH}_{2} \mathrm{PO}_{4}, 5 \mathrm{~m} M$ HEPES, and $5.5 \mathrm{~m} M$ glucose (pH 7.4). To evaluate the effect of the glucose concentration, the glucose concentration was increased to 30 and $55 \mathrm{mM}$. Mannitol, replacing glucose at equivalent osmolarities, was used as an osmotic control. These solutions, containing 5.5, 30, or $55 \mathrm{~m} M$ glucose or 30 or $55 \mathrm{~m} M$ mannitol, were superfused at a flow rate of $2 \mathrm{ml} / \mathrm{min}$. The measurement of $\left[\mathrm{Ca}^{2+}\right]_{\mathrm{i}}$ during superfusion is described below.

In order to investigate the source of $\mathrm{Ca}^{2+}$, we superfused 30 and $55 \mathrm{~m} M$ glucose Tyrode's solution with the removal of $\mathrm{Ca}^{2+}$. This nominally $0 \mathrm{Ca}^{2+}$ solution was prepared by chelating $\mathrm{Ca}^{2+}$ with $1 \mathrm{mM}$ EGTA from Tyrode's solution. Next, we investigated the role of store-operated $\mathrm{Ca}^{2+}$ influx (SOCI) using its inhibitor, SKF96365 (Tocris, Bristol, UK). In the preliminary experiment, the inhibitory effect was maximal at a dose of $50 \mu M$ in our cells (refer to the result in fig. 3B). SKF96365 at this dose was added to 30 and $55 \mathrm{~m} M$ glucose Tyrode's solution containing $2 \mathrm{mM} \mathrm{Ca}{ }^{2+}$ and superfused.

NCX function and expression were evaluated using MCs previously cultured in 5.5 or $30 \mathrm{~m} M$ glucose or $30 \mathrm{~m} M$ mannitol for 3 days. NCX activity was observed by activating it in the reverse mode by acute removal of extracellular $\mathrm{Na}^{+} . \mathrm{Na}^{+}$was removed from Tyrode's solution with isotonic replacement of N-methyl- $D$-glutamine. This so-called $\mathrm{Na}^{+}$-free solution was superfused and the intracellular $\mathrm{Ca}^{2+}$ spike representing NCX activity was measured. Next, we evaluated $\mathrm{Ca}^{2+}$ clearance via NCX. We first elevated intracellular $\mathrm{Ca}^{2+}$ by activating NCX in the forward mode with $\mathrm{Na}^{+}$-free solution. When MCs achieved a sufficient level of $\left[\mathrm{Ca}^{2+}\right]_{i}, \mathrm{Ca}^{2+}$ channels other than NCX were then blocked by adding $5 \mathrm{~m} M$ caffeine, $1 \mu M$ thapsigargin (Sigma Chemical Co., St Louis, Mo., USA), and $250 \mu M \mathrm{La}^{3+}$. Under this condition, $\mathrm{Na}^{+}$was acutely increased to $140 \mathrm{~m} M$ in the superfusion solution to elicit NCX in forward mode causing $\mathrm{Ca}^{2+}$ removal from the intracellular space.

Fig. 1. Experiments show a typical response of mesangial cells to angiotensin II (AT-II) in $5.5 \mathrm{~m} M$ glucose (A). Superfusion with 30 and $50 \mathrm{~m} M$ glucose increases $\left[\mathrm{Ca}^{2+}\right]_{i}$ spontaneously $(\mathbf{C}, \mathbf{D})$. The increases occurred in a dose-dependent manner to the glucose concentration. $\left[\mathrm{Ca}^{2+}\right]_{\mathrm{i}}$ is not changed by superfusion with $5.5 \mathrm{~m} M$ glucose (B) and 30 and $50 \mathrm{~m} M$ mannitol (E, F). Each fluorescence tracing is a representative of: 6 experiments (A), 21 experiments (B), 18 experiments (C), 16 experiments (D), 20 experiments (E), and 19 experiments $(\mathbf{F})$. 

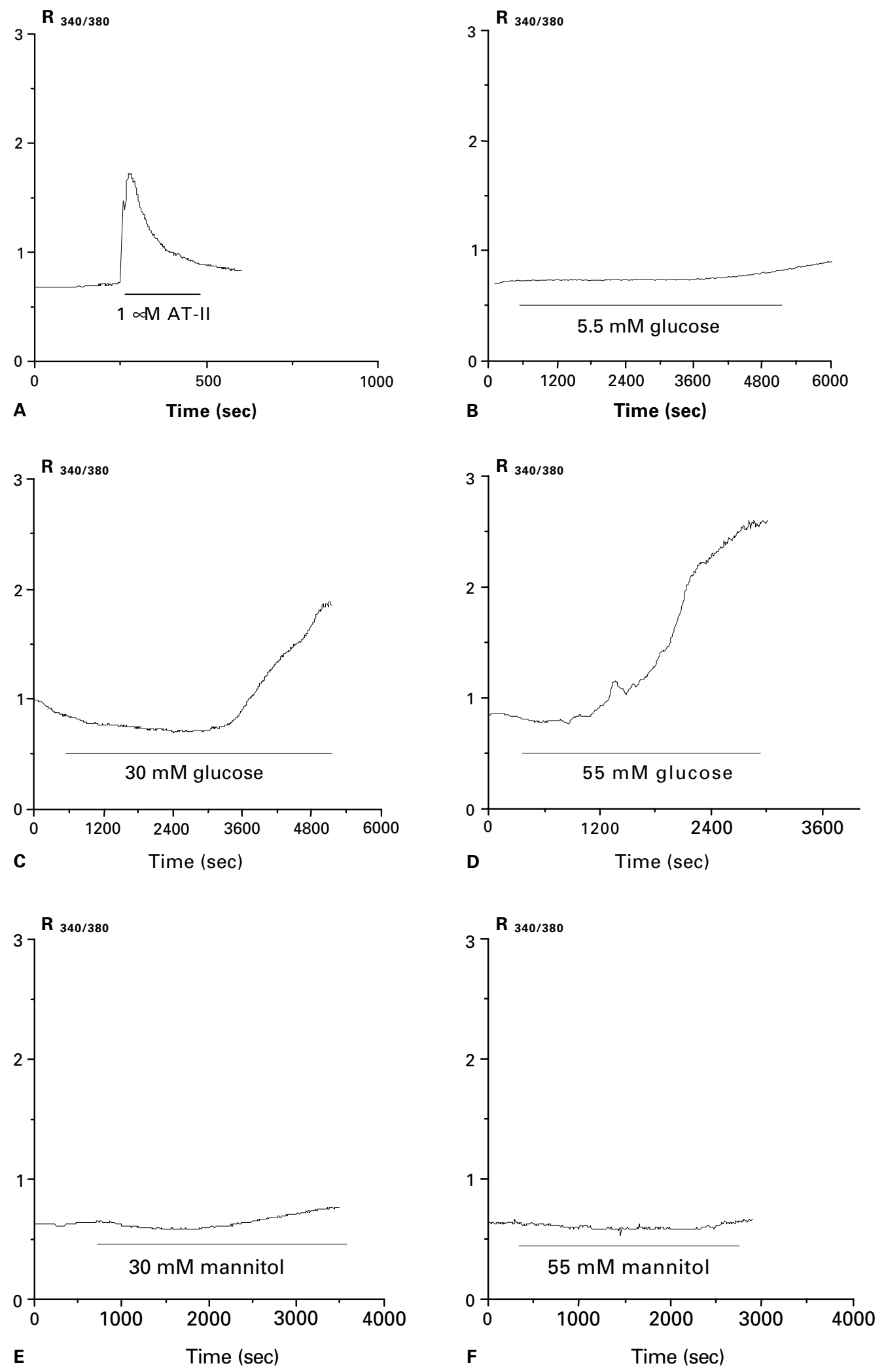

Basal $\left[\mathrm{Ca}^{2+}\right]_{\mathrm{i}}$ Regulation in Rat Mesangial 
Fig. 2. The increases in $\left[\mathrm{Ca}^{2+}\right]_{i}$ are significant at $1,500 \mathrm{~s}$ in $\mathrm{MCs}$ superfused with $50 \mathrm{~m} M$ glucose. At $3,500 \mathrm{~s},\left[\mathrm{Ca}^{2+}\right]_{\mathrm{i}}$ in $\mathrm{MCs}$ superfused with $30 \mathrm{mM}$ glucose also has a significant increase. $\left[\mathrm{Ca}^{2+}\right]_{\mathrm{i}}$ is higher in MCs superfused with $55 \mathrm{mM}$ glucose as compared to those with $30 \mathrm{~m} M$ glucose. ${ }^{*} \mathrm{p}<0.05$ to 5.5, $30 \mathrm{~m} M$ glucose and $30,55 \mathrm{~m} M$ mannitol. ${ }^{\dagger} \mathrm{p}<0.05$ to $55 \mathrm{mM}$ glucose at 500 and 1,500 s. $^{+}$p $<0.05$ to $5.5,50 \mathrm{~m} M$ glucose and $30,55 \mathrm{~m} M$ mannitol. Each column is representative of: 21 experiments with $5.5 \mathrm{mM}$ glucose; 18 experiments with $30 \mathrm{~m} M$ glucose; 16 experiments with $55 \mathrm{~m} M$ glucose; 20 experiments with $30 \mathrm{mM}$ mannitol, and 19 experiments with $55 \mathrm{mM}$ mannitol.

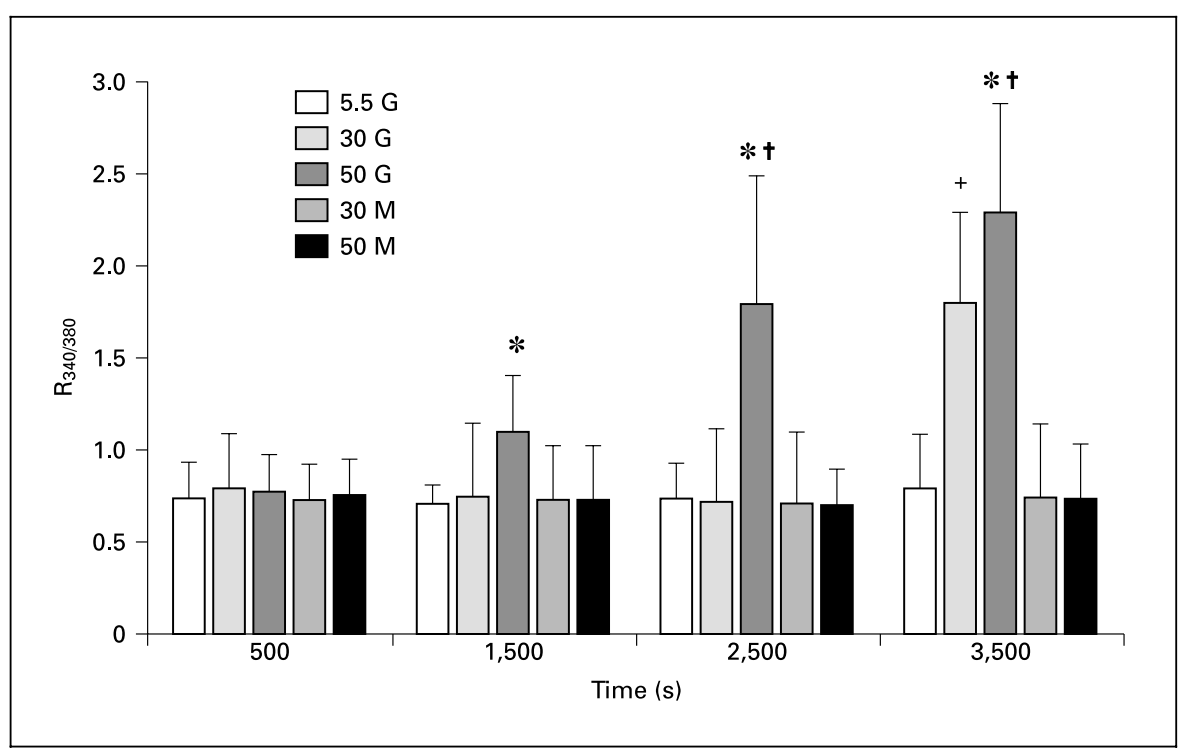

\section{Intracellular Calcium Measurement}

MCs were washed with PBS and incubated in $2 \mathrm{ml}$ of buffer ( $0.05 \%$ trypsin and $0.02 \%$ EDTA). They were then resuspended in Tyrode's solution containing $5 \mathrm{~m} M$ glucose and loaded with $3 \mu M$ fura-2 AM (Molecular Probe, Eugene, Oreg., USA), a $\mathrm{Ca}^{2+}$-sensitive intracellular probe, for $30 \mathrm{~min}$ at $37^{\circ} \mathrm{C}$. After loading, the MCs were washed with Tyrode's solution, spun down for $5 \mathrm{~min}$ at $580 \mathrm{~g}$. They were resuspended in Tyrode's solution and transferred to a recording chamber on an epifluorescence-inverted microscope (Nikon Diaphot 300, Tokyo, Japan). During the superfusion of experimental solutions as described above, fluorescence was measured using a cooled CCD camera (Photometrics PXL37, Tucson, Ariz., USA) and cellular $\mathrm{Ca}^{2+}$ imaging was processed using the Axon Imaging Workbench v.2.2 (Axon Instrument, Foster City, Calif., USA). The $\left[\mathrm{Ca}^{2+}\right]_{\mathrm{i}}$ is presented as $\mathrm{R}_{340 / 380}$, a ratio of fluorescence intensities excited by alternating illumination of 340 - and $380-\mathrm{nm}$ wavelength beams with emission collected at $500 \mathrm{~nm}$.

\section{Western Blot Analysis}

After being cultured in media containing 5.5 or $30 \mathrm{~m} M$ glucose or $30 \mathrm{~m} M$ mannitol for 3 days, MCs were homogenized in $4 \mathrm{ml}$ of a buffer solution containing $50 \mathrm{~m} M$ Tris/ $\mathrm{HCl}$ (pH 7.5), $2 \mathrm{~m} M$ EDTA, $10 \mathrm{~m} M$ EGTA, $5 \mathrm{~m} M$ dithiothreitol, $250 \mathrm{~m} M$ sucrose and $1 \%$ Triton $\mathrm{X}-100$ and the protease inhibitors $(0.5 \mu \mathrm{g} / \mathrm{ml}$ leupeptin, $5 \mu \mathrm{g} / \mathrm{ml}$ pepstatin, $1 \mathrm{~m} M$ PMSF, $1 \mathrm{~m} M$ benzamidine, $2 \mathrm{~m} M$ iodoacetamide, and $1 \mu \mathrm{g} / \mathrm{ml}$ aprotinin). The homogenate was then centrifuged at $10,000 \mathrm{~g}$ for $15 \mathrm{~min}$, and the resulting supernatant was centrifuged at $100,000 \mathrm{~g}$ for $90 \mathrm{~min}$. The crude microsomal pellet was resuspended in the same buffer as described above, frozen in liquid nitrogen, and stored at $-70^{\circ} \mathrm{C}$. Protein concentrations were determined by the Lowry method. Protein samples were separated by SDS/PAGE (8$16 \%$ gradient gel) and probed with rabbit anti-mouse sodium-calcium exchange monoclonal antibody (R3F1; Swant, Bellinzona, Switzerland). Bands were stained with R3F1 and developed by enhanced chemiluminescence (Amersham Pharmacia Biotech AB, Uppsala, Sweden) using horseradish peroxidase-conjugated goat anti-rabbit IgG and enhanced chemiluminescence. Each lane was loaded with $30 \mu \mathrm{g}$ of total protein.

\section{Statistical Analysis}

Each fluorescence tracing is representative of the indicated number of experiments conducted on a cell from separated cell cultures. $\mathrm{R}_{\max }$, the slope of $\mathrm{Ca}^{2+}$ clearance $\left(\mathrm{R}_{\max } / \mathrm{min}\right)$ and $\mathrm{NCX}$ protein expression (arbitrary units) are reported as the mean \pm SE for the indicated number of experiments. Statistical differences among the data were determined with Student's $t$ test and considered significant at $\mathrm{p}<0.05$.

\section{Results}

\section{Characteristics of Cells}

The cell studies showed the typical characteristics of the MCs; positive immunohistochemical staining for vimentin and desmin and negative staining for cytokeratin. They showed the typical characteristics of the $\left[\mathrm{Ca}^{2+}\right]_{i}$ of $\mathrm{MCs}$ in response to angiotensin II, which was identical to the previous studies (fig. 1A).

\section{Change in Basal $\left[\mathrm{Ca}^{2+}\right]_{i}$ and Role of Transmembrane Influx and SOCI}

Superfusion of the MCs with Tyrode's solution containing 30 or $55 \mathrm{~m} M$ glucose increased $\left[\mathrm{Ca}^{2+}\right]_{\mathrm{i}}$ spontaneously. The increase was not found with a normal glucose concentration $(5.5 \mathrm{mM})$ or mannitol at equivalent osmolarity (30 and $55 \mathrm{~m} M$; fig. $1 \mathrm{~B}-\mathrm{F}$ ). The increases started at about 3,000-3,500 s after superfusion with $30 \mathrm{~m} M$ glucose and at 1,000-1,500 s with $55 \mathrm{~m} M$ glucose. 

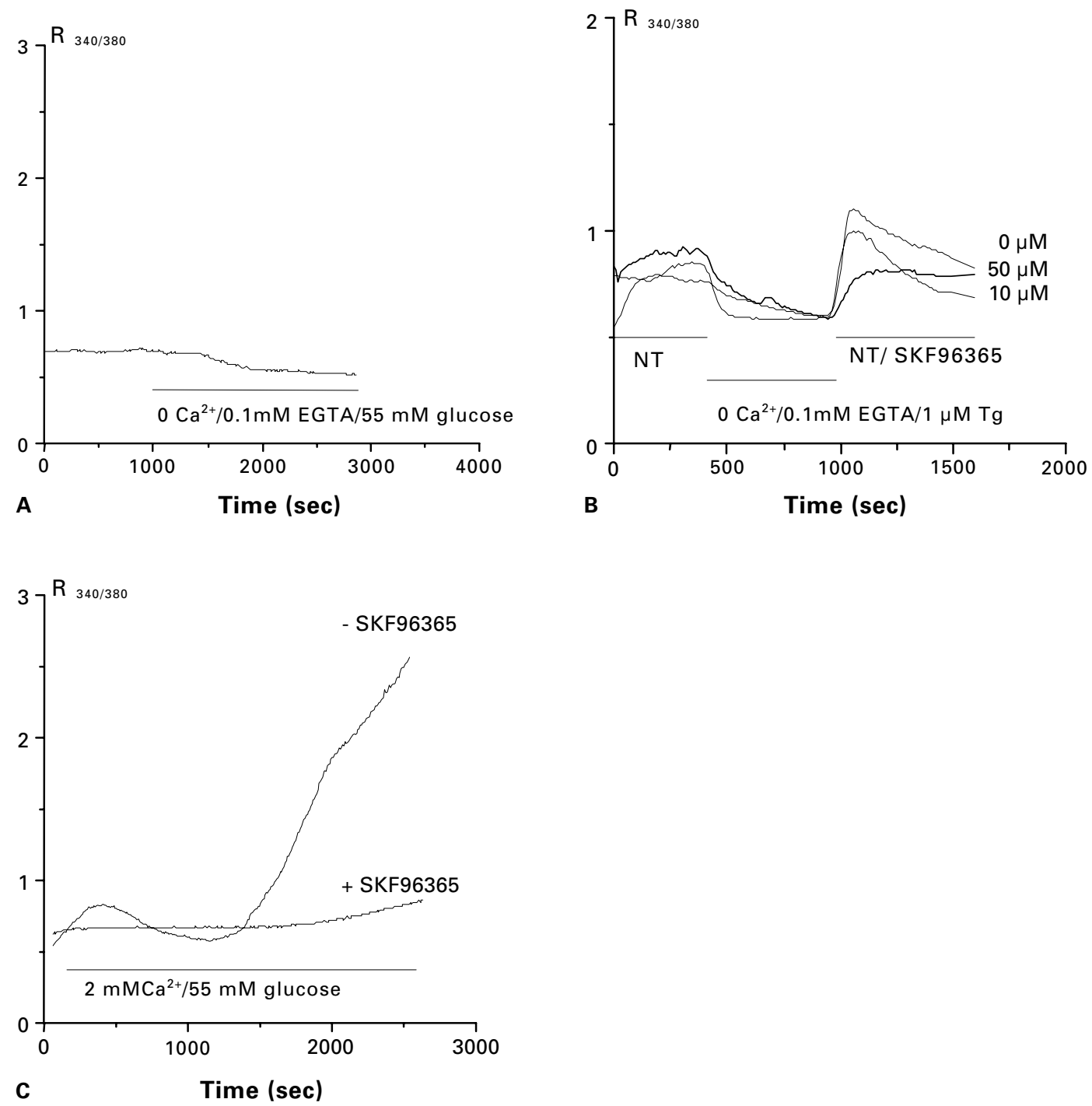

Fig. 3. High-glucose-induced $\left[\mathrm{Ca}^{2+}\right]_{\mathrm{i}}$ increase disappeared when extracellular $\mathrm{Ca}^{2+}$ was chelated with $0.1 \mathrm{~m} M$ EGTA (A). The maximal inhibitory dose of SKF96365 is $50 \mu M$ in the present experimental condition (B). At normal extracellular $\mathrm{Ca}^{2+}$ concentrations, addition of $50 \mu M$ SKF96365 prevents the increase in $\left[\mathrm{Ca}^{2+}\right]_{\mathrm{i}}$ after the exposure to $30 \mathrm{~m} M$ (not shown) and $50 \mathrm{~m} M$ glucose (C). Each fluorescence tracing is a representative of: 17 experiments (A), and 16 experiments with -SKF96365 and 15 experiments with +SKF96365 (C).

$\left[\mathrm{Ca}^{2+}\right]_{\mathrm{i}}$ increased significantly in the MCs superfused with $55 \mathrm{~m} M$ glucose at $1,500 \mathrm{~s}$. At $3,500 \mathrm{~s}$, the $\left[\mathrm{Ca}^{2+}\right]_{\mathrm{i}}$ of the MCs superfused with $30 \mathrm{~m} M$ glucose increased significantly (fig. 2). The $\left[\mathrm{Ca}^{2+}\right]_{\mathrm{i}}$ at $3,500 \mathrm{~s}$ was higher with $55 \mathrm{~m} M$ glucose $(2.32 \pm 0.46)$ than with $30 \mathrm{~m} M$ glucose $(1.87 \pm 0.51 ; \mathrm{p}<0.05)$.

The removal of extracellular $\mathrm{Ca}^{2+}$ by chelation with $0.1 \mathrm{~m} M$ EGTA completely prevented the increase in

Basal $\left[\mathrm{Ca}^{2+}\right]_{\mathrm{i}}$ Regulation in Rat Mesangial Cell
$\left[\mathrm{Ca}^{2+}\right]_{\mathrm{i}}$ both with 30 and $55 \mathrm{~m} M$ glucose (fig. $3 \mathrm{~A}$ ). This suggests that the high-glucose-induced increase in $\left[\mathrm{Ca}^{2+}\right]_{i}$ originates from the transmembrane influx but not from intracellular $\mathrm{Ca}^{2+}$ stores. The addition of SKF96365 to the normal $\mathrm{Ca}^{2+}$ solution also completely blocked the high-glucose-induced increase in $\left[\mathrm{Ca}^{2+}\right]_{i}$. The result suggests that transmembrane influx occurs through SOCI (fig. 3C). 


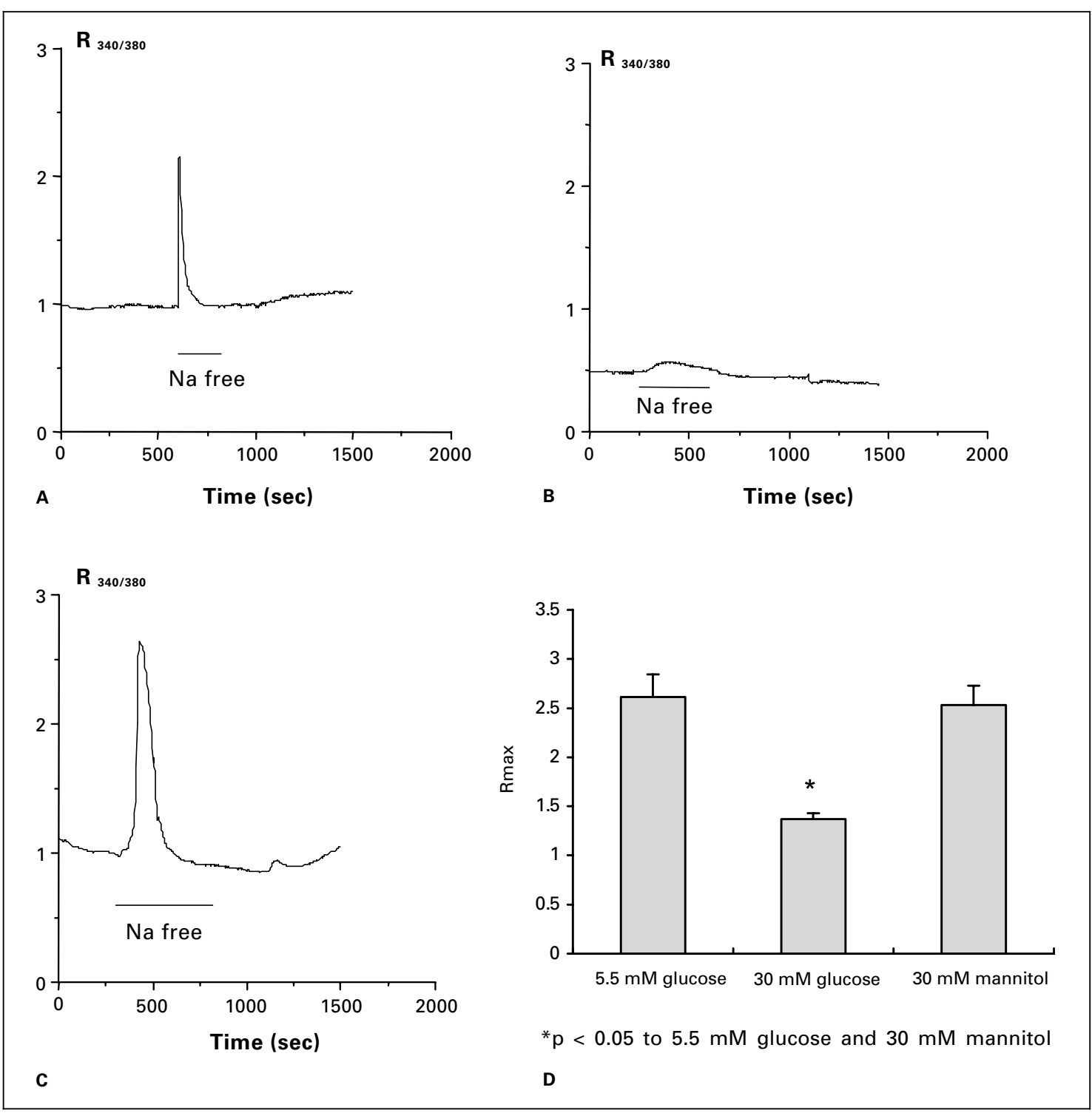

Fig. 4. $\mathrm{Ca}^{2+}$ spike representing $\mathrm{Na}^{+}-\mathrm{Ca}^{2+}$ exchanger activity is normally elicited by acute removal of extracellular $\mathrm{Na}^{+}$ in MCs cultured in $5.5 \mathrm{~m} M$ glucose medium (A) and $30 \mathrm{~m} M$ mannitol medium (C). The elicitation of $\mathrm{Na}^{+}-\mathrm{Ca}^{2+} \mathrm{ex}^{-}$ changer activity did not occur in MCs cultured in $30 \mathrm{~m} M$ glucose medium (B). Peak $\left[\mathrm{Ca}^{2+}\right]_{\mathrm{i}}\left(\mathrm{R}_{\max }\right)$ is significantly lower in MCs cultured in $30 \mathrm{~m} M$ glucose than in $5.5 \mathrm{~m} M$ glucose and $30 \mathrm{~m} M$ mannitol (D). Each fluorescence tracing and column is representative of: 32 experiments with $5.5 \mathrm{~m} M$ glucose; 37 experiments with $30 \mathrm{~m} M$ glucose, and 24 experiments with $30 \mathrm{~m} M$ mannitol.

The Activity, $\mathrm{Ca}^{2+}$ Clearance Ability, and Expression of $\mathrm{Na}^{+}-\mathrm{Ca}^{2+}$ Exchanger

When NCX was elicited in the reverse mode using $\mathrm{Na}^{+}$-free Tyrode's solution, the $\mathrm{Ca}^{2+}$ spike that represents NCX activity was markedly depressed in MCs cultured in $30 \mathrm{~m} M$ glucose medium. This was not found in MCs cultured in $5.5 \mathrm{~m} M$ glucose media and $30 \mathrm{~m} M$ mannitol medium (fig. 4). Peak $\left[\mathrm{Ca}^{2+}\right]_{\text {i }}$ following NCX activation $\left(\mathrm{R}_{\max }\right)$ was $1.37 \pm 0.06$ in MCs cultured in $30 \mathrm{~m} M$ glucose, which was significantly lower than $2.61 \pm 0.23$ and $2.53 \pm 0.20$ in MCs cultured in $5.5 \mathrm{~m} M$ glucose and $30 \mathrm{~m} M$ mannitol respectively ( $\mathrm{p}<0.05$; fig. 4D).

As described in Methods, we elevated intracellular $\mathrm{Ca}^{2+}$ using $\mathrm{Na}^{+}$-free solution to evaluate intracellular $\mathrm{Ca}^{2+}$ 


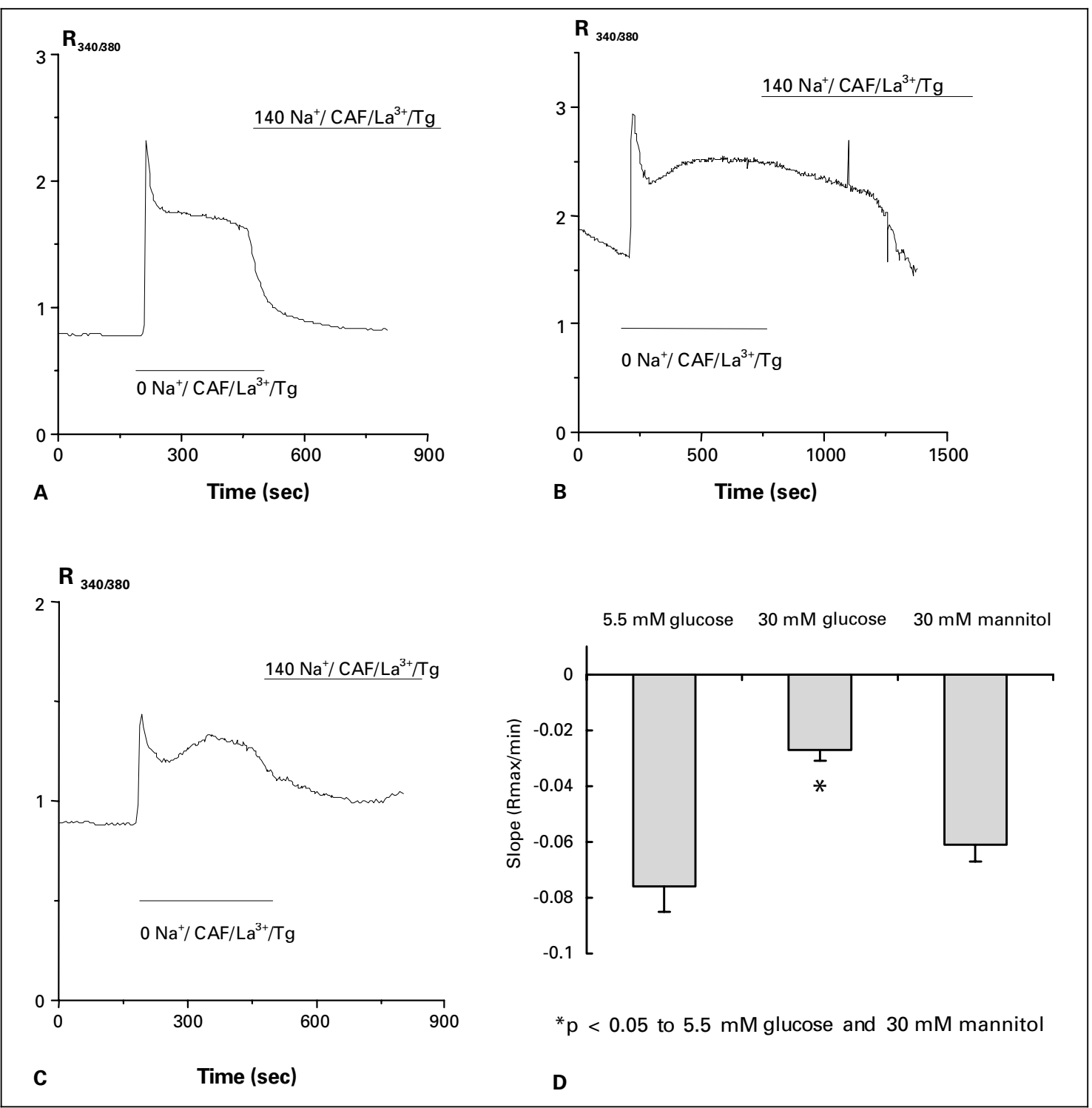

Fig. 5. $\mathrm{Ca}^{2+}$ clearance via $\mathrm{Na}^{+}-\mathrm{Ca}^{2+}$ exchanger is normal in $\mathrm{MCs}$ cultured in $5.5 \mathrm{~m} M$ glucose (A) and $30 \mathrm{~m} M$ mannitol medium (C), but decreased in MCs cultured in $30 \mathrm{~m} M$ glucose medium (B). The slope of $\mathrm{Ca}^{2+}$ clearance $(\mathrm{R} / \mathrm{min})$ is significantly lower in MCs cultured in $30 \mathrm{~m} M$ glucose than in $5.5 \mathrm{~m} M$ glucose and $30 \mathrm{~m} M$ mannitol (D). Each fluorescence tracing and column is a representative of: 20 experiments with $5.5 \mathrm{~m} M$ glucose; 19 experiments with $30 \mathrm{~m} M$ glucose, and 21 experiments with $30 \mathrm{~m} M$ mannitol.

clearance. In this step, a sufficient intracellular $\mathrm{Ca}^{2+}$ level could be achieved in 20 of $21(95.2 \%), 19$ of $32(59.4 \%)$, and 21 of $24(87.5 \%)$ MCs cultured in 5.5 or $30 \mathrm{~m} M$ glucose, and $30 \mathrm{~m} M$ mannitol medium respectively. $\mathrm{Ca}^{2+}$ clearance was evaluated in these cells. As a result, $\mathrm{Ca}^{2+}$ clearance was decreased in MCs cultured in $30 \mathrm{~m} M$ glucose as compared to those cultured in $5.5 \mathrm{~m} M$ glucose or
$30 \mathrm{~m} M$ mannitol (fig. 5). The slope of $\mathrm{Ca}^{2+}$ clearance $(\mathrm{R} / \mathrm{min})$ was $-0.027 \pm 0.004$ in MCs cultured in $30 \mathrm{mM}$ glucose, which was significantly lower than $-0.076 \pm$ 0.009 and $-0.061 \pm 0.006$ in MCs cultured in $5.5 \mathrm{mM}$ glucose and $30 \mathrm{~m} M$ mannitol, respectively (p $<0.05$; fig. $5 \mathrm{D}$ ). In Western blot analysis, the protein expression of $70 \mathrm{kD}$ NCX protein was decreased in MCs cultured 


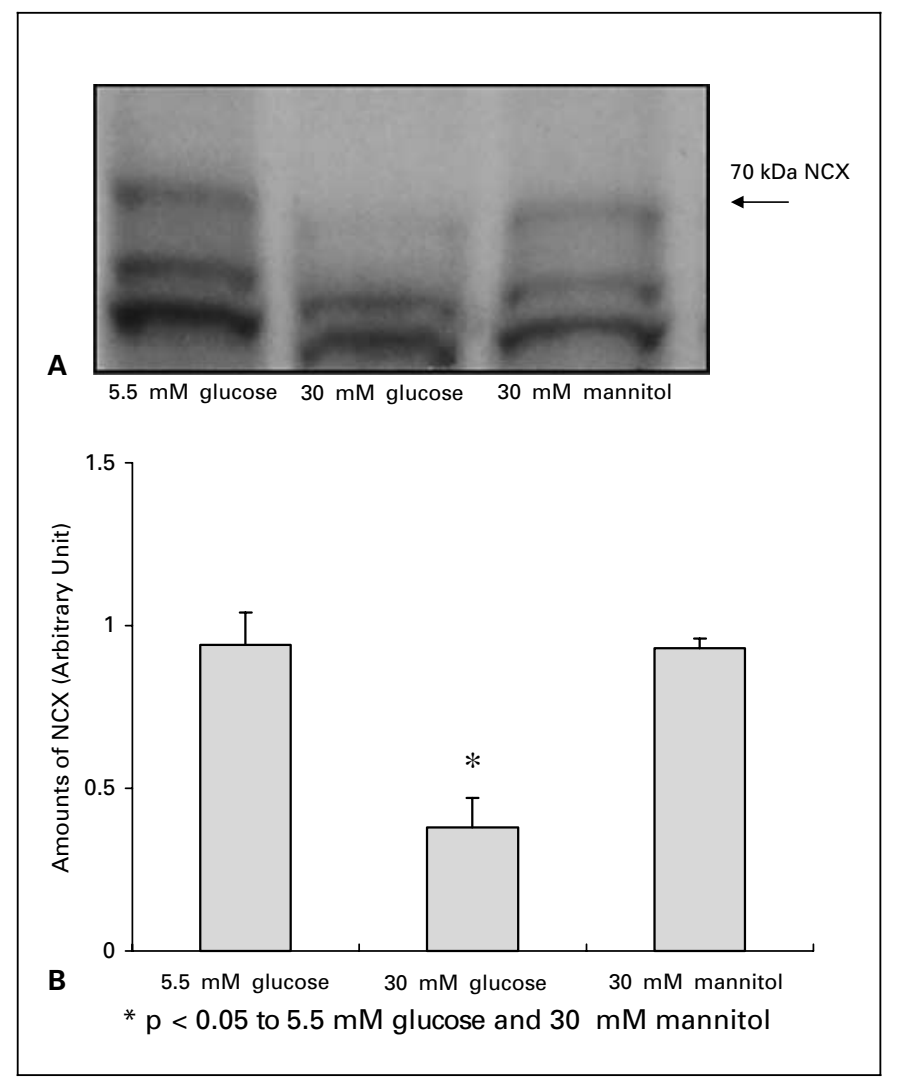

Fig. 6. MCs cultured in high glucose show decreased expression of $70 \mathrm{kDa} \mathrm{Na}{ }^{+}-\mathrm{Ca}^{2+}$ exchanger (A). Densitometric analysis revealed that the expression in MCs cultured in $30 \mathrm{~m} M$ glucose is significantly depressed as compared to MCs in $5.5 \mathrm{~m} M$ glucose and $30 \mathrm{~m} M$ mannitol medium (B). Each fluorescence tracing and column is a representative of: 7 experiments with $5.5 \mathrm{~m} M$ glucose; 8 experiments with $30 \mathrm{~m} M$ glucose, and 7 experiments with $30 \mathrm{~m} M$ mannitol.

in $30 \mathrm{~m} M$ glucose medium. Densitometric analysis revealed that this was significant when compared to those cultured in $5.5 \mathrm{~m} M$ glucose and $30 \mathrm{~m} M$ mannitol medium (fig. 6).

\section{Discussion}

Altered regulation of $\mathrm{Ca}^{2+}$ may play a key role in multiple cellular dysfunctions. A sustained tonic upregulation of $\left[\mathrm{Ca}^{2+}\right]_{i}$ is capable of activating a number of potentially harmful processes. Some of these occur through the activation of hydrolytic enzymes such as phospholipase $A_{2}$, $\mathrm{Ca}^{2+}$-activated proteases, and $\mathrm{Ca}^{2+}$-activated endonucleases, whereas others occur through the modulation of signaling pathways including ligand-activated kinases as well as a number of intracellular messengers [6-8]. To maintain intracellular $\mathrm{Ca}^{2+}$ homeostasis, a complex regulatory mechanism is required that integrates the release from internal stores, transmembrane influx from and efflux to the extracellular space, and sequestration into internal stores [14-18]. There are three kinds of $\mathrm{Ca}^{2+}$-regulating pathways clearly identified in rat MCs: inositol trisphosphate ( $\mathrm{Ins}_{3}$ )-mediated release from intracellular stores; SOCI, and NCX. The voltage-operated L-type calcium channel, another important pathway, has rarely been investigated in these cells. One study reported that this channel is also present in MCs and, if this is the case, its function is expected to be related to agonist-induced contraction as in other cells [19].

$\mathrm{Ca}^{2+}$ release from intracellular stores requires stimulation of vasoconstrictive hormones, angiotensin II, arginine vasopressin or thromboxane mimetics which act as stimulators. Binding of these molecules to phospholipase C-coupling receptor induces the release of equimolar water-soluble Ins $\mathrm{P}_{3}$ and diacylglycerol from membrane phosphoinositides. Consequently, $\mathrm{InsP}_{3}$ mobilizes $\mathrm{Ca}^{2+}$ from the intracellular stores, resulting in an explosive elevation in $\left[\mathrm{Ca}^{2+}\right]_{i}$ and subsequent influx of $\mathrm{Ca}^{2+}$ through SOCI. SOCI, also called 'capacitative' or $\mathrm{Ca}^{2+}$ release-activated $\mathrm{Ca}^{2+}$ channel influx, sustains $\mathrm{Ca}^{2+}$ influx following Ins $\mathrm{P}_{3}$-mediated $\mathrm{Ca}^{2+}$ release [14-18, 20]. Recent investigations revealed that the $\left[\mathrm{Ca}^{2+}\right]_{i}$ response of MCs to vasoactive hormones is blunted in high-glucose conditions including the function of SOCI [10-13]. These changes contribute to the loss of contractility of MCs in response to vasoactive hormones and are relevant to hyperfiltration and microalbuminuria in early diabetic nephropathy.

As diabetic nephropathy progresses, the pathophysiological features other than contractile abnormality appear, such as phenotypic changes, deranged proliferative rate, apoptosis and death. These $\mathrm{Ca}^{2+}$-dependent cellular dysfunctions are related to a sustained 'tonic' elevation, rather than a responsive increase in stimulators of $\left[\mathrm{Ca}^{2+}\right]_{i}$. The adverse role of elevated basal $\left[\mathrm{Ca}^{2+}\right]_{\mathrm{i}}$ have already been reported in many other cells in various pathophysiological conditions [21-25]. Two recent studies report that intracellular $\mathrm{Ca}^{2+}$ signals are related to the regulation of proliferation in MCs [26, 27]. Therefore, we focused on the effect of high glucose on basal $\left[\mathrm{Ca}^{2+}\right]_{\mathrm{i}}$ and its regulation in MCs that are not stimulated.

The present study shows that high glucose can alter the basal intracellular $\mathrm{Ca}^{2+}$ pool. The feature of $\left[\mathrm{Ca}^{2+}\right]_{i}$ increase was rather gradual and sustained, which is quite different from the curve by stimulation. It does not match the $\left[\mathrm{Ca}^{2+}\right]_{i}$ curve by $\mathrm{InsP}_{3}$-mediated release from intracellular stores. 
The increased $\mathrm{Ca}^{2+}$ seems to come entirely from transmembrane influx from the extracellular space in that $0 \mathrm{Ca}^{2+}$ perfusion results in complete disappearance of a high-glucose-induced increase in $\left[\mathrm{Ca}^{2+}\right]_{\mathrm{i}}$. To identify the $\mathrm{Ca}^{2+}$ channel responsible for the high-glucose-induced transmembrane influx, we blocked SOCI with SKF96365 since it is the only kind of transmembrane $\mathrm{Ca}^{2+}$ channel confirmed in $\mathrm{MCs}[10,28]$. As a result, the high-glucose-induced increase in $\left[\mathrm{Ca}^{2+}\right]_{\mathrm{i}}$ was blocked by SKF96365, suggesting that the entry of $\mathrm{Ca}^{2+}$ occurs mainly through SOCI.

Two important points from our findings are that $\mathrm{InsP}_{3^{-}}$ mediated release from intracellular stores does not evolve and that SOCI is a main pathway in the process of the high-glucose-induced increase in $\left[\mathrm{Ca}^{2+}\right]_{i}$, even without involvement in the InsP $\mathrm{P}_{3}$-mediated process. Further investigations could reveal details of the mechanism in the near future. To clarify the role of SOCI, investigation is mandatory in two directions. One is the mechanism by which $\mathrm{Ca}^{2+}$ enters through this channel in the absence of agonist stimulation and/or depletion of intracellular $\mathrm{Ca}^{2+}$ stores. Primarily, SOCI is activated following the prior agonist stimulation through the release of $\mathrm{Ca}^{2+}$ from intracellular stores or a putative 'influx factor' coupled to the depletion in $\mathrm{Ca}^{2+}$ stores [13]. In the stimulated MC models, the response of SOCI to the stimulators was decreased in the high-glucose condition [10-13]. Another aspect is whether the activity of SOCI by itself is changed and, if so, in which direction will it be. The change in the resting activity of SOCI in the high-glucose condition is still unknown. Our results also cannot provide further information since the $\mathrm{Ca}^{2+}$ influx via SOCI occurred spontaneously and was beyond the normal regulating mechanism of SOCI in the present study. A simple malfunction of the channel might permit $\mathrm{Ca}^{2+}$ flux regardless of its activity. Therefore, the investigations on this issue will provide further interesting information on the mechanism of $\mathrm{Ca}^{2+}$ homeostasis in diabetic nephropathy.

In the next step, we focused on the NCX function. Intracellular $\mathrm{Ca}^{2+}$ homeostasis is not only maintained in resting conditions $[29,30]$, but also in stimulated conditions [31, 32]. Normally it transports $\mathrm{Na}^{+}$into and $\mathrm{Ca}^{2+}$ out of the cells, the so-called forward-mode activity, but it can also be activated by the reverse mode. To observe the presence and activity of NCX, the reverse mode of NCX activity is commonly elicited by the acute removal of extracellular $\mathrm{Na}^{+}$. We evaluated the activity of NCX in the reverse mode using this popular experimental method. In our results, the activity of NCX was depressed in MCs cultured in the high-glucose condition. Peak $\left[\mathrm{Ca}^{2+}\right]_{\mathrm{i}}$ following NCX stimulation was significantly decreased by high glucose as compared to normal glucose or mannitol. Therefore, we evaluated the actual $\mathrm{Ca}^{2+}$ clearance via NCX using a further complex method activating NCX in the forward mode. First, we increased intracellular $\mathrm{Ca}^{2+}$ by activating the reverse mode of NCX, as described above. Since NCX activity is depressed in MCs cultured in high glucose, achieving a sufficient intracellular $\mathrm{Ca}^{2+}$ was not easy in these cells. The addition of thapsigargin might be helpful in achieving sufficient intracellular $\mathrm{Ca}^{2+}$ since it causes a transient sustained $\left[\mathrm{Ca}^{2+}\right]_{\mathrm{i}}$ elevation by depleting $\mathrm{Ca}^{2+}$ from the intracellular stores. In the condition of increased intracellular $\mathrm{Ca}^{2+}$, extracellular $\mathrm{Na}^{+}$was acutely restored to the physiological concentration to activate NCX in the forward mode. To exclude the possible sources of $\mathrm{Ca}^{2+}$ removal rather than NCX, $\mathrm{La}^{3+}$, a PMCA inhibitor, and thapsigargin and caffeine, a blocker of reuptake to intracellular stores, were added during this procedure. As a result, intracellular $\mathrm{Ca}^{2+}$ was rapidly decreased in MCs cultured in normal glucose or mannitol. In contrast, the decrease in $\mathrm{Ca}^{2+}$ was blunted in MCs cultured in high glucose, showing a significantly decreased slope.

The alterations in NCX activity have frequently been reported in various pathological conditions. For example, it relates to contractile dysfunction, arrhythmogenesis and remodeling of cardiac muscles [33-35], to abnormal $\mathrm{Ca}^{2+}$ regulation in pancreatic cells $[36,37]$, and to the abnormal development of brain cells [38, 39]. In cultured human and rat MCs, the expression of NCX was shown to be related to the rate of growth and life span [40-42]. One of the important implications of the present study is that NCX function of MCs can also be altered in diabetic conditions. The change in NCX function may relate to a number of pathophysiological changes that depend on the intracellular $\mathrm{Ca}^{2+}$ signal. In Western blot analysis, the depression in NCX by high glucose was revealed to occur at the level of protein expression. The investigation on the pathophysiological role of altered NCX in MCs will be an interesting subject in the field of diabetic nephropathy. Further investigations are also required to define the mechanism by which high glucose decreases protein expression of NCX.

In conclusions, we found that high glucose by itself increases basal $\left[\mathrm{Ca}^{2+}\right]_{\mathrm{i}}$ in unstimulated MCs. $\left[\mathrm{Ca}^{2+}\right]_{\mathrm{i}}$ was increased in a dose-dependent manner with glucose concentrations. The entry of extracellular $\mathrm{Ca}^{2+}$, perhaps mainly through SOCI, was the source of $\mathrm{Ca}^{2+}$ during the high-glucose-induced increase in $\left[\mathrm{Ca}^{2+}\right]_{i}$. The activity of NCX and its $\mathrm{Ca}^{2+}$ clearance ability decreased in MCs cultured in the high-glucose condition. The inhibited function of NCX occurred at the level of protein expression. 
The present study provides novel insight into the pathophysiological mechanisms of diabetic nephropathy since many cellular functions depend critically on intracellular $\mathrm{Ca}^{2+}$ homeostasis.

\section{Acknowledgements}

This work was supported by Inha University Research Grant (INHA-21871).

\section{References}

1 Mauer SM: Structural-functional correlations of diabetic nephropathy. Kidney Int 1994;45: 612-622.

2 Adler S: Structure-function relationships in diabetic nephropathy: Lessons and limitations. Kidney Int Suppl 1997;60:S42-S45.

3 Lee HB, Ha H, Kim SI, Ziyadeh FN: Diabetic kidney disease research: Where do we stand at the turn of the century? Kidney Int Suppl 2000; 77:S1-S2.

4 McDonald F, Somasundaram B, McCann TJ, Mason WT, Meikle MC: Calcium waves in fluid flow stimulated osteoblasts are $\mathrm{G}$ protein mediated. Arch Biochem Biophys 1996;326: 31-38.

5 Jayaraman T, Marks AR: Calcineurin is downstream of the inositol 1,4,5-trisphosphate receptor in the apoptotic and cell growth pathways. J Biol Chem 2001;275:6417-6420.

6 Trump BF, Berezesky IK: Calcium-mediated cell injury and cell death. FASEB J 1995;9: 219-228.

7 Trump BF, Berezesky IK: The role of altered $\left[\mathrm{Ca}^{2+}\right]_{i}$ regulation in apoptosis, oncosis, and necrosis. Biochim Biophys Acta 1996;1313. 173-178.

8 McConkey DJ, Orrenius S: The role of calcium in the regulation of apoptosis. Biochem Biophys Res Commun 1997;239:357-366.

9 Kikkawa R, Kitamura E, Fukiwara Y, Arimura T, Haneda M, Shigeta Y: Impaired contractile responsiveness of diabetic glomeruli to angiotensin II: A possible indication of mesangial dysfunction in diabetes mellitus. Biochem Biophys Res Commun 1986;136:1185-1190.

10 Mene P, Teti A, Pugliese F, Cinotti GA: Calcium release-activated calcium influx in cultured human mesangial cells. Kidney Int 1994; 46:122-128.

11 Hurst RD, Stevanovic ZS, Munk S, Derylo B, Zhou X, Meer J, Silverberg M, Whiteside CI: Glomerular mesangial cell altered contractility in high glucose is $\mathrm{Ca}^{2+}$ independent. Diabetes 1995;44:759-766.

12 Mene P, Pugliese F, Cinotti GA: Regulation of capacitative calcium influx in cultured human mesangial cells: Roles of protein kinase $\mathrm{C}$ and calmodulin. J Am Soc Nephrol 1996;7:983990

13 Mene P, Pugliese F, Pricci F, Di Mario U, Cinotti GA, Pugliese F: High glucose level inhibits capacitative $\mathrm{Ca}^{2+}$ influx in cultured rat mesangial cells by a protein kinase C-dependent mechanism. Diabetologia 1997;40:521527.

14 Rink TJ, Merritt JE: Calcium signalling. Curr Opin Cell Biol 1990;2:198-205.

15 Berridge MJ: Inositol trisphosphate and calcium signalling. Nature 1993;361:315-325.
16 Carafoli E: Intracellular calcium homeostasis. Annu Rev Biochem 1987;56:395-433.

17 Carafoli E, James P, Strehler EE: Structurefunction relationships in the calcium pump of plasma membranes. Prog Clin Biol Res 1993; 332:181-193.

18 Taylor CW, Traynor D: Calcium and inositol trisphosphate receptors. J Membr Biol 1995; 145:109-118.

19 Hall DA, Carmines PK, Sansom SC: Dihydropyridine-sensitive $\mathrm{Ca}^{2+}$ channels in human glomerular mesangial cells. Am J Physiol 2000; 278:F97-103.

20 Mene P, Simonson MS, Dunn MJ: Phospholipids in signal transduction of mesangial cells. Am J Physiol 1989;256:F375-386.

21 Yamamoto N, Maki A, Swann JD, Berezesky IK, Trump BF: Induction of immediate early and stress genes in rat proximal tubule epithelium following injury: The significance of cytosolic ionized calcium. Ren Fail 1993;15:163171.

22 Tsukamoto A, Kaneko Y: Thapsigargin, a $\mathrm{Ca}^{2+}$-ATPase inhibitor, depletes the intracellular $\mathrm{Ca}^{2+}$ pool and induces apoptosis in human hepatoma cells. Cell Biol Int 1993;17:969970.

23 Golovina VA: Cell proliferation is associated with enhanced capacitative $\mathrm{Ca}^{2+}$ entry in human arterial myocytes. Am J Physiol 1999;277: C343-C349.

24 Sugiura T, Imai E, Moriyama T, Horio M, Hori M: Calcium channel blockers inhibit proliferation and matrix production in rat mesangial cells: Possible mechanism of suppression of AP-1 and CREB activities. Nephron 2000;85: 71-80.

25 Sweeney M, McDaniel SS, Platoshyn O, Zhang S, Yu Y, Lapp BR, Zhao Y, Thistlethwaite PA, Yuan JX: Role of capacitative $\mathrm{Ca}^{2+}$ entry in bronchial contraction and remodeling. J Appl Physiol 2002;192:1594-1602.

26 Whiteside C, Munk S, Zhou X, Miralem T, Templeton DM: Chelation of intracellular calcium prevents mesangial cell proliferative responsiveness. J Am Soc Nephrol 1998;9:1425.

27 Saleh H, Schlatter E, Lang D, Pauels HG, Heidenreich S: Regulation of mesangial cell apoptosis and proliferation by intracellular $\mathrm{Ca}^{2+}$ signals. Kidney Int 2000;58:1876-1884.

28 Ma R, Smith S, Child A, Carmines PK, Sansom SC: Store-operated $\mathrm{Ca}^{2+}$ channels in human glomerular mesangial cells. Am J Physiol 2000;278:F954-961.

29 DiPolo R, Beauge L: Regulation of $\mathrm{Na}^{+}-\mathrm{Ca}^{2+}$ exchange. An overview. Ann NY Acad Sci 1991;39:100-111.
30 Dominguez JH, Juhaszova M, Kleiboeker SB, Hale CC, Feister HA: $\mathrm{Na}^{+}-\mathrm{Ca}^{2+}$ exchanger of rat proximal tubule: Gene expression and subcellular localization. Am J Physiol 1992;263: F945-950.

31 Ashida T, Kuramochi M, Omae T: Increased sodium-calcium exchange in arterial smooth muscle of spontaneously hypertensive rats. Hypertension 1989;13:890-895.

32 Batlle DC, Godinich M, LaPointe MS, Munoz E, Carone F, Mehring N: Extracellular $\mathrm{Na}^{+}$ dependency of free cytosolic $\mathrm{Ca}^{2+}$ regulation in aortic vascular smooth muscle cells. Am J Physiol 1991;261:C845-C856.

33 Schweda F, Seebauer H, Kramer BK, Kurtz A: Functional role of sodium-calcium exchange in the regulation of renal vascular resistance. Am J Physiol Renal Physiol 2001;280:F155-161.

34 Sipido KR, Volders PG, Vos MA, Verdonck F: Altered $\mathrm{Na}^{+} / \mathrm{Ca}^{2+}$ exchange activity in cardiac hypertrophy and heart failure: a new target for therapy? Cardiovasc Res 2002;53:782-805.

35 Takimoto E, Yao A, Toko H, Takano H, Shimoyama M, Sonoda M, Wakimoto K, Takahashi T, Akazawa H, Mizukami M, Nagai T, Nagai R, and Komuro I: Sodium calcium exchanger plays a key role in alteration of cardiac function in response to pressure overload. FASEB J 2002;16:373-378.

36 Yoshihashi K, Shibuya I, Kanno T: Contribution of $\mathrm{Na}^{+} / \mathrm{Ca}^{2+}$ exchanger in maintaining $\left[\mathrm{Ca}^{2+}\right]_{\mathrm{i}}$ at a stable state in rat pancreatic islets. Jpn J Physiol 1996;46:473-480.

37 Yoshihashi K, Habara Y: Contribution of $\mathrm{Na}^{+}$ $\mathrm{Ca}^{2+}$ exchanger to glucose-induced $\left[\mathrm{Ca}^{2+}\right]_{\mathrm{i}}$ increase in rat pancreatic islets. Jpn $\mathrm{J}$ Physiol 1999;49:71-80.

38 Matsuda T, Takuma K, Nishiguchi E, Hashimoto H, Azuma J, Baba A: Involvement of $\mathrm{Na}^{+}-\mathrm{Ca}^{2+}$ exchanger in reperfusion-induced delayed cell death of cultured rat astrocytes. Eur J Neurosci 1996;8:951-958.

39 Matsuda T, Baba A: Response of $\mathrm{Na}^{+} / \mathrm{Ca}^{2+}$ antiporter to ischemia and glial/neuronal death. Nippon Yakurigaku Zasshi 1998;111: 13-19.

40 Sakaue M, Nakamura H, Kaneko I, Kawasaki Y, Arakawa N, Hashimoto H, Koyama Y, Baba A, Matsuda T: $\mathrm{Na}^{+}-\mathrm{Ca}^{2+}$ exchanger isoforms in rat neuronal preparations: Different changes in their expression during postnatal development. Brain Res 2000;881:212-216.

41 Mene P, Pugliese F, Faraggiana T, Cinotti GA Identification and characteristics of a Na${ }^{+} / \mathrm{Ca}^{2+}$ exchanger in cultured human mesangial cells. Kidney Int 1990;38:1199-1205.

42 Mene P, Pugliese F, Cinotti GA: Regulation of $\mathrm{Na}^{+}-\mathrm{Ca}^{2+}$ exchange in cultured human mesangial cells. Am J Physiol 1991;261:F466-473. 